\title{
In Vitro Effects of Silicon on the Action Patterns of Sugarcane Acid Invertase
}

\author{
Alex G. Alexander' \\ INTRODUCTION
}

Recent evidence suggests that the element silicon ( $\mathrm{Si}$ ) plays an important role in sucrose production by sugarcane. Workers in Hawaii $(7)^{2}$ and Mauritius (21) increased production by applying $\mathrm{Si}$-bearing materials to cane fields. Ayers $(6)$ found that the $\mathrm{Si}$ of calcium silicate slag may act as a growth stimulant for cane grown on low-Si soils. The consensus that $\mathrm{Si}$ affects manganese uptake has been verified by sand-culture experiments in Puerto Rico. ${ }^{3}$

More specific roles of $\mathrm{Si}$ in cane biochemistry are beginning to be explored. An apparent in viro inhibition of invertase $(5)$ has been confirmed by in vitro experiments. ${ }^{4}$ The enzymes amylase and phosphatase were also inhibited by Si. The inhibition of invertase was considered to be especially important since the enzyme vastly alters a series of sugar substrates (3). It was felt that more detailed studies of invertase action patterns would be instructive if $\mathrm{Si}$ was incorporated in the reaction digests. This paper summarizes experiments which have further clarified the nature of invertase action and have revealed an extensive ctapacity of Si to affect sugar transformations.

\section{EXPERIMENTAL PROCEDURE}

Invertase was prepared from lyophilized immature storage tissue taken from 16-week-old plants grown in sand culture. ${ }^{5}$ Powdered tissues were $\mathrm{cx}$ tracted with water at room temperature. The extracts were clarified by passage through cheesecloth and by subsequent centrifuging at 3,000 r.p.m. Invertase was precipitated from the supernatant liquid with solid ammonium sulfate between 38- and 52-percent saturation. The enzyme-containing protein was taken up in water, reclarified by centrifuging, and dialyzed against water for $\left(i\right.$ hours at $4{ }^{\circ} \mathrm{C}$. The invertase preparation was then fractionated by filtration through a $2.5 \times 40-\mathrm{cm}$. column of $\mathrm{G}-200$ Sepha-

${ }^{1}$ Plant Physiologist, Agricultural Experiment Station, Mayagüez Campus, University of Puerto Rieo, Río l'iedras, l’.lR.

2 It alic numbers in parent heses refer to Literature Cited, pp. 321-2.

${ }^{3}$ 1)ata submitted for publication, Proc. Intnl. Soc. Sugar Cane Technol., Taiwan, 19 (i8.

${ }^{4}$ )ata submitted for publication, Proc. Intul. Soc. Sugar Cane Technol., Taiwan, 1968.

5 Variety P.R. 980. 
$\operatorname{dex}^{6}$, a procedure which successfully isolates invertase from the bulk of noncatalytic protein. All fractions derived from the gel column were assayed for invertase as described previously (2), and peak-activity fractions were combined and refrigerated at $4^{\circ} \mathrm{C}$.

The standard invertase digest was composed as follows: $1.0 \mathrm{ml}$. of acetate buffer ( $\mathrm{pH}$.5.5); $1.0 \mathrm{ml}$. of 5-percent substrate solution (sucrose, raffinose, melezitose, stachyose, turanose); $0.5 \mathrm{ml}$. of Si solution (sufficient to make a final Si concentration of 0.10 to $100 \mu$ moles of Si per milliliter of digest); and $0.5 \mathrm{ml}$. of enzyme preparation. The standard reaction proceeded for 2 hours at $37^{\circ} \mathrm{C}$. and was terminated by a 10 -minute submersion in boiling water. Reference vessels contained water in place of $\mathrm{Si}$ solution. The Si source for all experiments was sodium metasilicate, $\mathrm{Na}_{\mathrm{a}_{2} \mathrm{SiO}_{3}} \cdot 9 \mathrm{H}_{2} \mathrm{O}$, which in solution forms orthosilicic acid, $\mathrm{Si}(\mathrm{OH})_{4}(17)$.

Samples of inactivated invertase digests were chromatographed on Whatman No. 1 filter paper, using the solvent mixture butanol-pyridine-water $(6: 4: 3, \mathrm{v} / \mathrm{v})$ in one dimension. Spots representing substrate and products were developed by the silver nitrate dip method (8).

\section{RESULTS AND DISCUSSION}

\section{SUBSTRATES AND PRODUCTS OF INVERTASE}

A total of five sugars was found to be acted upon by invertase, including sucrose, raffinose, melezitose, stachyose, and turanose (fig. 1). All reactions except that against melezitose were altered in some manner by $\mathrm{Si}$.

Invertase action against raffinose is particluarly complex in that four products appear in contrast to the two products from sucrose (fig. 2). It is a slow reaction requiring more than 6 hours for all products to be clearly distinguished.

Raffinose is a nonreducing trisaccharide which occurs widely in the plant world. It accumulates in mother liquors during preparation of sucrose from the sugar beet $(9, \mathrm{p} .518)$. Its structure includes the configurations for melibiose and sucrose:

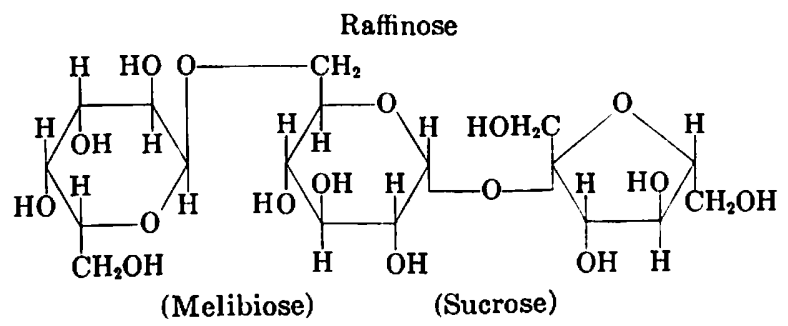

Complete acid hydrolysis yields $1 \mathrm{~mol}$ each of D-glucose, D-fructose, and

' Farmacia of Fine Chemicals, Rochester, Minn. 
D-galactose. Mild acid hydrolysis produces only D-fructose and melibiose, as does yeast invertase. However, since cane invertase gives four products, it is likely that both the $1 \rightarrow 6$ and $1 \rightarrow 2$ linkages are broken. The predominance of fructose in figure 2 can be explained by a dual hydrolysis

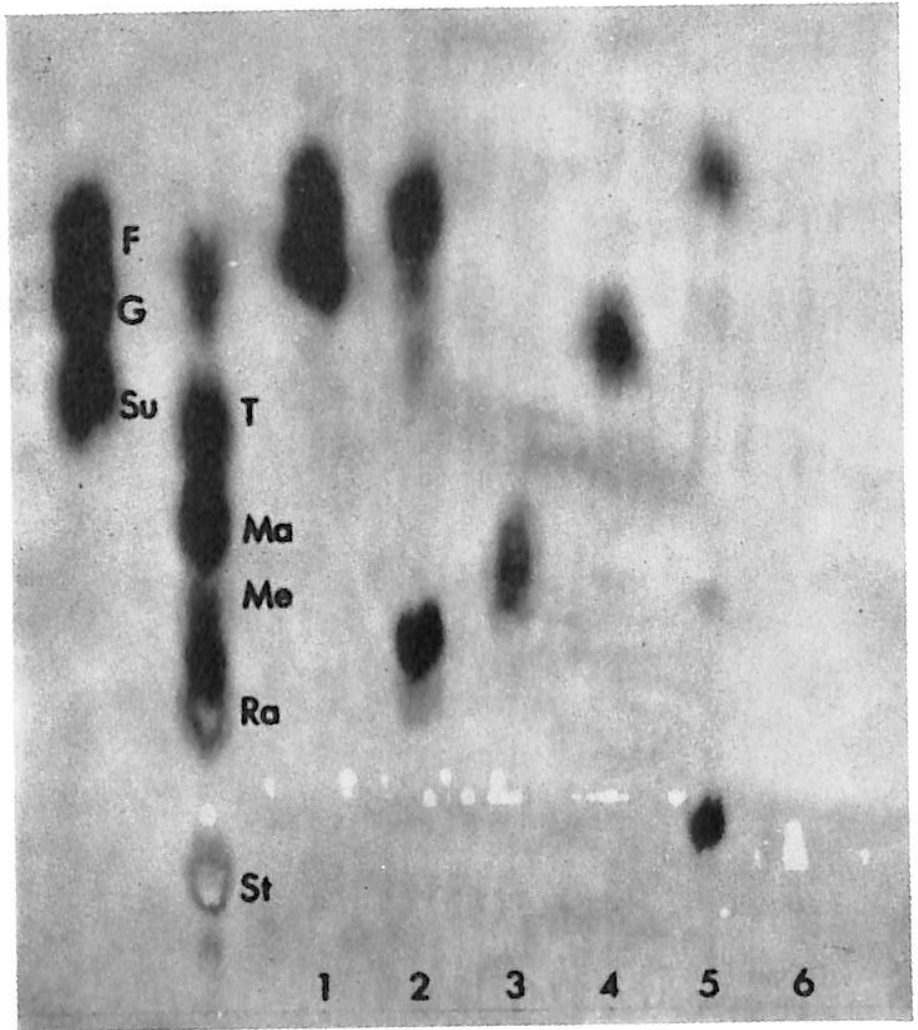

FIG. 1.- Substrates attacked by sugarcane acid invertase. Nos. 1 through 5 represent the following substrates acted upon by invertase: 1 , sucrose; 2 , raffinose; 3 , melezitose; 4, turanose; and 5, stachyose. No. 6 represents the invertase preparation without substrate. Letters in the left-hand columns signify the following reference sugars: F, fructose; G, glucose; Su, sucrose; T, turanose; Ma, maltose; Me, melezitose; Ra, raffinose, and St, stachyose.

which includes direct action upon raffinose and secondary attacks upon the intermediate product sucrose.

Silicon added to invertase digests completely halted all activity against sucrose and raffinose (fig. 3). The effective inhibitor concentration was between 3 and $5 \mu$ moles per milliliter.

Employment of stachyose as substrate yielded two distinct products 
and traces of a third. Stachyose is a nonreducing tetrasaccharide which is converted by acid or invertase to the trisaccharide manninotriose and Dfructose (9). Methylation studies by Laidlaw and Wylam (15) plus the

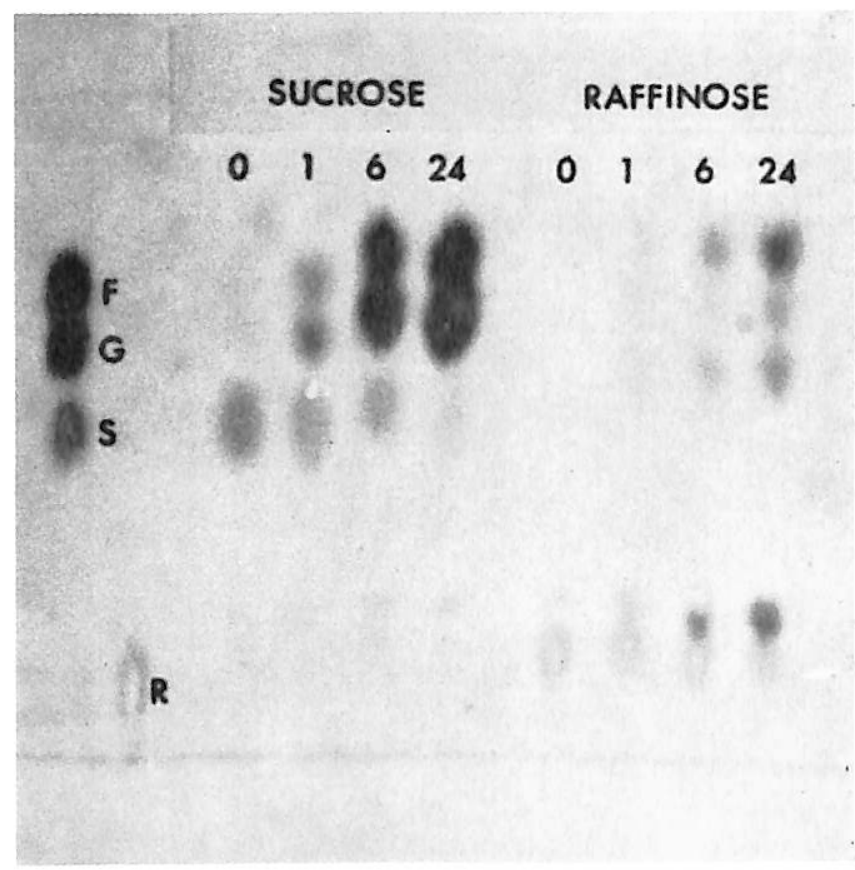

FIg. 2.-Action of sugarcane acid invertase on the substrates sucrose and raffinose over a prolonged period of time. The numerals 0 through 24 signify hours.

periodate oxidation work of Herissey (11) indicate a $1 \rightarrow 6$ linkage between all units except a terminal D-glucosyl-D-fructose:

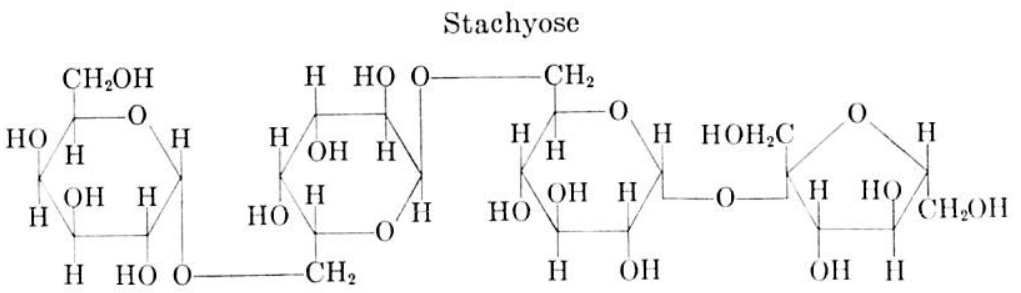

The cleavage of fructose from stachyose by cane invertase is clearly illustrated by figure 4 . The two additional products are further evidence of $1 \rightarrow 6$ linkage hydrolysis by the cane enyzme. Again, Si inhibited all invertase action in the concentration range of 3 to $5 \mu$ moles per milliliter. 
EFFECTS OF SI ON INVERTASE-MEDIATED SUGAR TRANSFORMATIONS

The present experiments support the contention that $\mathrm{Si}$ is an effective inhibitor of cane invertase. The possibility exists that $\mathrm{Si}$ could be used to retard sucrose inversion among growing plants or in cut stalks awaiting the factory. Of further interest, from a strictly analytical standpoint, is the relatively precise level at which Si becomes an effective inhibitor. It has been shown that this concentration is slightly more than $3 \mu$ moles for cane invert-

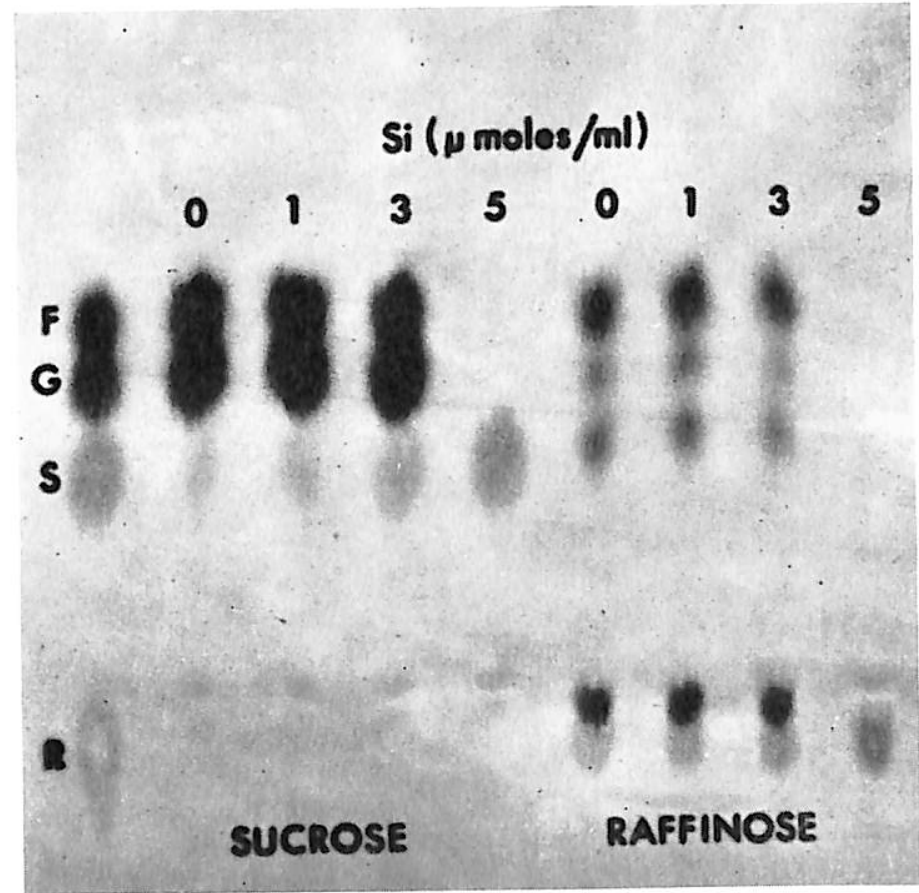

FIG. 3.- Silicon inhibition of invertase acting upon sucrose and raffinose.

ase, and slightly more than $4 \mu$ moles for amylase. It is not improbable that an enzyme test for soluble $\mathrm{Si}$ in tissue extracts could be developed on this basis.

A different aspect of $\mathrm{Si}$ action was encountered while attempting to inhibit the action of invertase against turanose (fig. 4). Rather than retard the enzyme, there appeared instead an increased number and quantity of products in response to increasing $\mathrm{Si}$. At $5 \mu$ moles of Si, the amount of glucose liberated was vastly increased and an additional sugar product appeared. Figure 5 illustrates a subsequent treatment series in which $\mathrm{Si}$ was raised to $9 \mu$ moles. The higher level caused a total loss of turanose and yielded a fourth 
distinct product believed to be fructose. Melezitose was also evident in these digests, plus an unknown sugar of slightly less mobility than raffinose.

Turanose is a reducing disaccharide which yields D-fructose and D-glu-

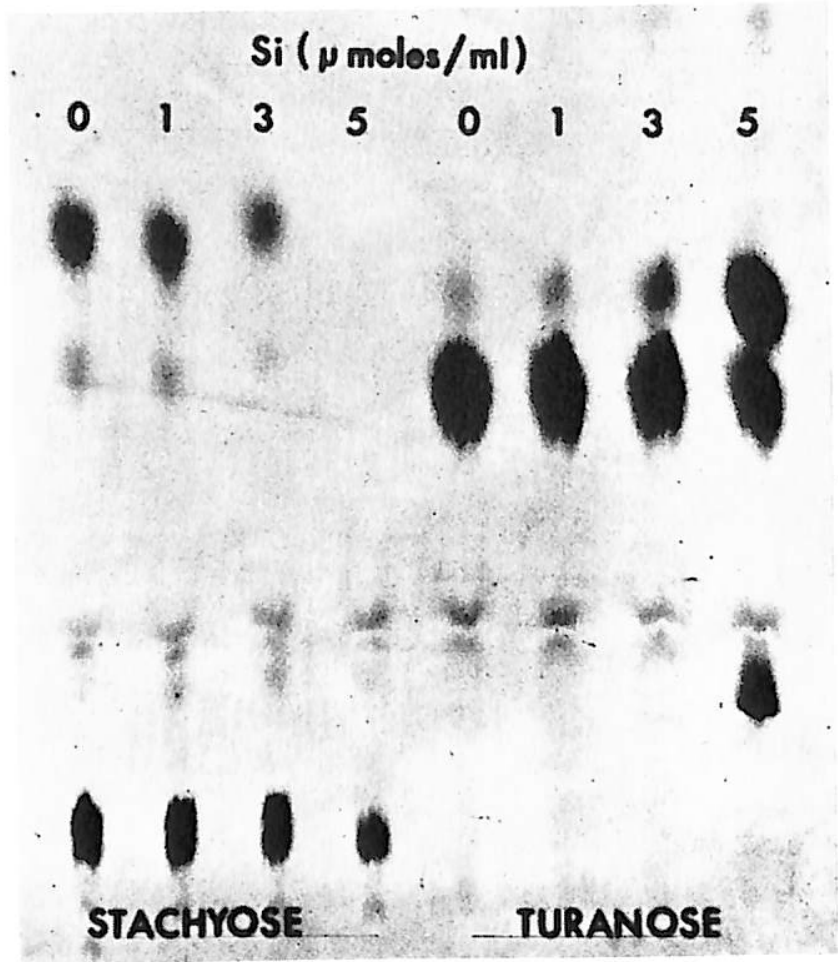

FIG, 4.-Effects of increasing Si levels on invertase action against stachyose and turanose.

cose upon hydrolysis by yeast $\alpha$-D-glucosidase. Hence it is considered an $\alpha$-D-glucoside:

Turanose

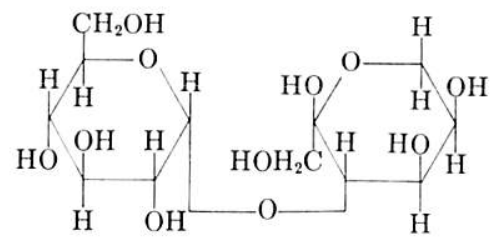

Since the mutarotation of turanose resembles that of fructose, it is believed that an interconversion exists between pyranose and furanose isomers 
rather than between $\alpha, \beta$-isomers (12). This may help account for the "late" appearance of fructose (furanose) in the above digests, if in fact fructose originally maintained a pyranose configuration.

Three important concepts are underlined by the Si-invertase-turanose data. First, the yield of four products by attack upon a disaccharide implies a highly versatile action pattern by cane invertase. Simple hydrolysis

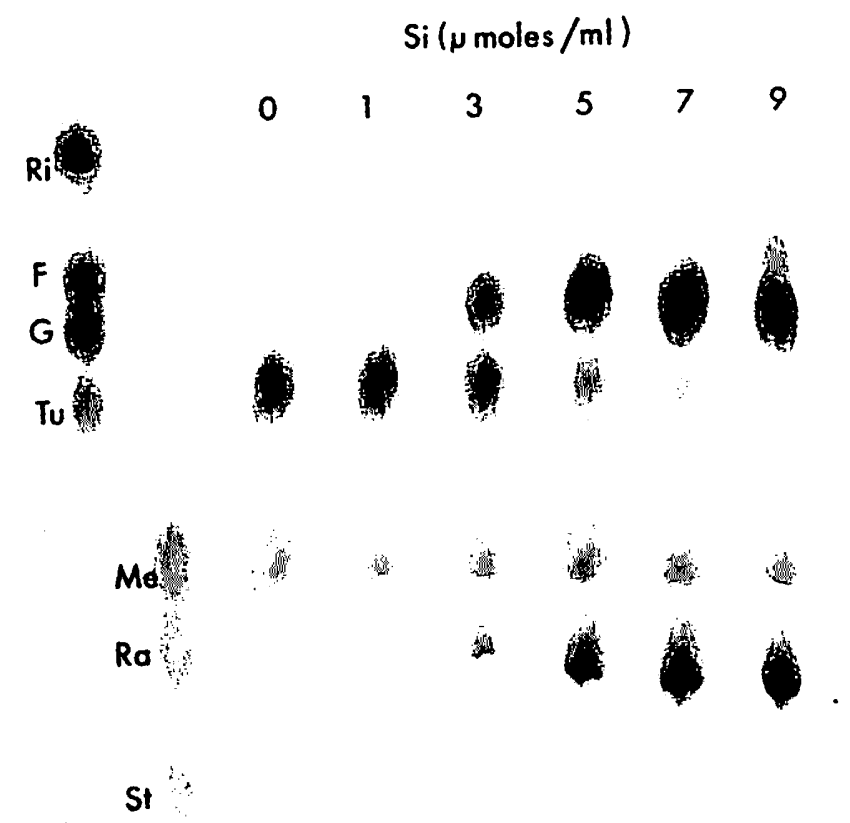

Fic. 5. - Singar transformations induced by Si added to invert ase-turanose digests.

is not an adecuate explanation, rather, an interconversion of mono-, di-, or trisaccharide: must be involved. Second, inhibition of invertase by $\mathrm{Si}$, i.e., loss of its capacity to hydrolyze sucrose, does not mean that all of the enzyme's work potential is lost. Invertase clearly continued to demolish turanose after the Si level had surpassed that needed to stop sucrose inversion. Conversely, Si was apparently required to bring about this latter activity by invertase.

A third concept is the apparent capacity of $\mathrm{Si}$ to enter chemically into 
enzyme or enzyme-substrate configurations. The unusually abrupt and irreversible inhibitory action of Si led to us suggest some type of Si crystallization around the enzyme. ${ }^{4}$ This would be initiated when a very critical concentration of silicic acid was reached. In the diatom, where silica deposition has been given serious study, an absolute requirement of the element is needed for cell division $(19,14,16)$. Diatom silica is known to vary as to specific gravity, particle size, state of hydration and porosity (17). It is possible that a silicic acid gel such as that believed to comprise a foamlike substructure of diatom shells (10) forms around sugarcane invertase.

Such a hypothetical catalyst might cease to function against certain substrates while retaining or gaining in its capacity to attack others. In particular the $\beta$-D-fructosidic and $\alpha$-D-glucosidic linkages of sucrose and raffinose would no longer be subject to attack. According to "Anfinsen's Law", once an acceptable geometric solution has been gained for a problem in protein function, a degree of structure variability can be tolerated so long as essential amino acid sequence and function is maintained (18). The proposed $\mathrm{Si}$ inhibition of invertase accordingly suggests no change in amino acid sequence or function, but rather implies a new geometric solution for a new problem of protein function.

Yeast invertase has long been considered a polysaccharide-protein (20) or a carbohydrate-protein (1). Quastel and Yates (19) proposed that the oppositely charged groups of invertase were bridged by sucrose. Cane invertase is believed to be a carbohydrate-protein complex in which a number of sugars can serve better than sucrose. After stopping activity by prolonged dialysis, Alexander (2) fully reactivated the enzyme with traces of sucrose, and still greater activity was obtained with equimolar amounts of maltose, galactose, glucose, and fructose. Perhaps the invertase carbohydrate lost during the present dialysis and gel filtration steps might be replaced by a silicic acid gel. However, in vivo data support a severe $\mathrm{Si}$ inhibition within intact cells having all possible protective or stabilizing factors fully available $(5)^{3}$.

Whereas a critical minimum Si level triggers invertase inhibition, another type of enzyme action seems to proceed in proportion to increasing Si concentration. Figure $6, \mathrm{~A}$, shows that when sucrose is substrate, a nonstaining, relatively immobile product appears in the presence of $9 \mu$ moles of $\mathrm{Si}$. At 81 $\mu$ moles there is an almost continuous mass of variably staining material extending from the point of application to the substrate front. Similar results are obtained with raffinose serving as substrate (fig. 6,B.) The product material behaves much like fragments of starch chains attacked by sugarcane amylase (4). Possibly the substrate and product molecules are orientated in short chains or clusters within a silicic acid gel. The latter would supposedly 

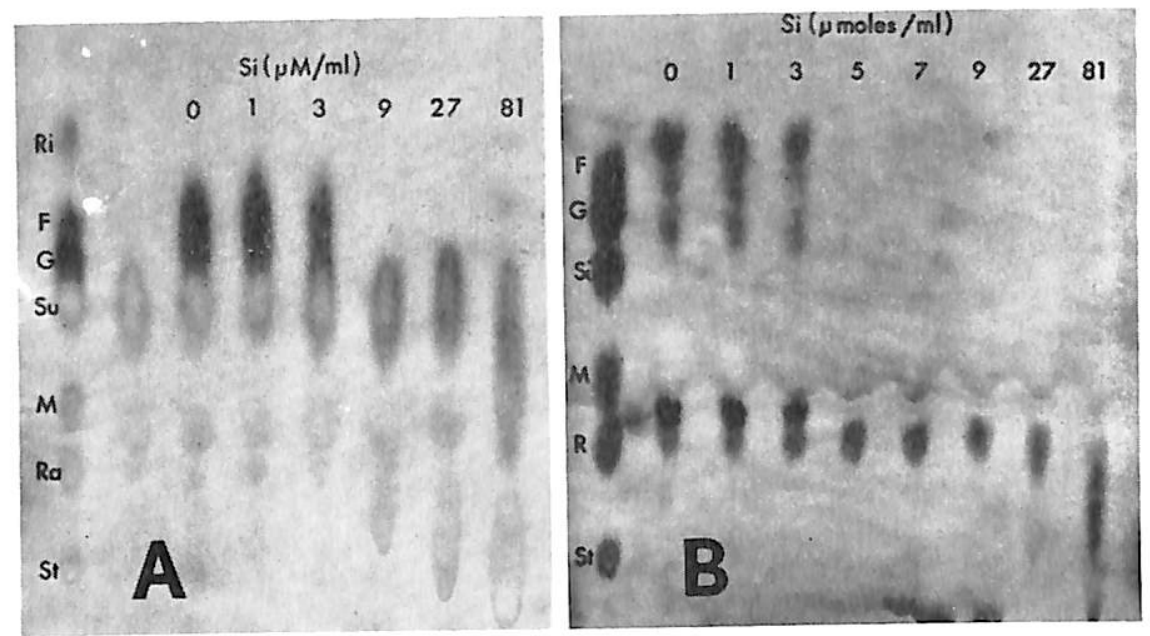

FIG. 6.-Effects of increasing Si levels on invertase acting against sucrose (A) and raffinose (B).

gain in size and strength with increasing Si concentration and thereby involve a greater mass of "trapped" molecules.

\section{SUMMARY}

In vitro studies of invertase action patterns were conducted in the presence of silicon $(\mathrm{Si})$. This element is known to inhibit the enzyme both in living tissues and cell-free preparations. Substrates included sucrose, raffinose, stachyose, and turanose. Sugarcane acid invertase was prepared from lyophilized immature storage tissue and was partially purified by salt fractionation, dialysis, and gel filtration. Enzyme products were studied by paper chromatography.

Two products, fructose and glucose, were quickly obtained in large quantity from sucrose. Against raffinose the reaction proceeded more slowly but yielded a total of four products. This suggests a powerful work potential of cane invertase since complete acid hydrolysis of raffinose gives only three products. It is proposed that both $1 \rightarrow 6$ and $1 \rightarrow 2$ linkages are broken. Fructose appears by direct hydrolysis of raffinose and by secondary attacks upon the intermediate product sucrose.

Use of stachyose as substrate gave additional evidence for hydrolysis of the $1 \rightarrow 6$ linkage. Three products were obtained in the presence of only one $1 \rightarrow 2$ fructosidic linkage.

Incorporation of Si into invertase digests abruptly terminated the reactions against sucrose, raffinose and stachyose. The effective Si concentra- 
tion was slightly more than $3 \mu$ moles of Si per milliliter of digest. Significance of the invertase inhibition is mentioned both from the standpoint of increasing sucrose yield and as an analytical indicator of silicic acid content of plant tissues.

When the disaccharide turanose was employed as substrate, increasing $\mathrm{Si}$ levels gave additional products rather than suspended enyme action. Four products appeared in the presence of $9 \mu$ moles of $\mathrm{Si}$. The substrates sucrose and raffinose yielded masses of variably-staining products at $\mathrm{Si}$ levels above $27 \mu$ moles per milliliter. The latter products were of low chromatographic mobility and resembled fragments of hydrolyzed starch.

To account for $\mathrm{Si}$ action on invertase it is proposed that a silicic acid gel forms around the enzyme in direct proportion to Si concentration. Inhibition of sucrose hydrolysis does not stem from severe protein structural changes. Rather, the hypothetical, gel-encased enzyme might cease to function against one substrate while retaining or increasing its capacity to attack others.

\section{RESUMEN}

Se llevaron a cabo estudios in vitro de los patrones de acción de la invertasa en presencia del silicio. Se sabe que este elemento inhibe la enzima tanto en los tejidos vivientes como en las preparaciones de los tejidos liofilizados. Los substratos incluían sacarosa, rafinosa, estaquiosa y turanosa. Se preparó invertasa ácida de caña de azúcar de tejidos reservantes inmaduros liofolizados, purificándose con una fraccionación de sal, diálisis y filtración de gela. Se estudiaron productos enzimáticos mediante la cromatograf ía sobre papel.

Se obtuvieron con rapidez de la sacarosa, dos productos en grandes cantidades: fructosa y glucosa. La reacción con la rafinosa fue más lenta, pero produjo cuatro distintos productos. Este hecho sugiere un fuerte potencial por parte de la invertasa de la caña, ya que una hidrólisis ácida completa de la rafinosa sólo produce tres. Se propone que los enlaces del $1 \rightarrow 6$ y del $1 \rightarrow 2$ quedan rotos. La fructosa aparece por hidrólisis directa de la rafinosia y mediante ataques secundarios contra el producto intermedio, o sea, la sacarosa.

El uso de la estaquiosa como un substrato presentó evidencia adicional de la hidrólisis del enlace del $1 \rightarrow 6$. Se obtuvieron tres productos en presencia de un solo enlace, el $1 \rightarrow 2$ fructosídico.

$\mathrm{Al}$ añadir $\mathrm{Si}$ a los digestos de invertasa terminaron abruptamente las reacciones con la sacarosa, la rafinosa y la estaquiosa. La concentración efectiva de Si excedió ligeramente $3 \mu$ moles de silicio por mililitro de digesto. Se menciona el significado que tiene el efecto inhibidor de la invertasa tanto desde el punto de vista del aumento que genera en el rendimiento de la sacarosa como de su valor como indicador analítico del contenido de ácido silícico en los tejidos de las plantas. 
Cuando se usó el disacárido turanosa como substrato, el aumento en los niveles de Si produjo otros productos adicionales más bien que una suspensión de la acción enzimática. Aparecieron cuatro productos en presencia de $9 \mu$ moles de Si. Los substratos sacarosa y rafinosa produjeron conjuntos de productos teñibles en grados variables a niveles en exceso de 27 $\mu$ moles por mililitro. Dichos productos eran de una baja movilidad cromatográfica y semejaban fragmentos de almidón hidrolizado.

Para explicar la acción del Si sobre la invertasa se propone la formación de una gela de ácido silícico alrededor de la enzima y en proporción directa a la concentración del $\mathrm{Si}$. La inhibición de la hidrólisis de la sacarosa no resulta de los cambios estructurales severos de la proteína. Más bien, la enzima hipotética encerrada en la gela pudiera dejar de funcionar contra un sustrato, reteniendo o aumentando, sin embargo, su capacidad para atacar a otros.

\section{LITERATURE CITED}

1. Adams, M., and Hudson, C. S., New methods for the purification of invertase and some properties of the resulting products, J. Amer. Chem. Soc. 65: 1359-68, 1943.

2. Alexander, A. G., Hydrolytic proteins of sugarcane: The acid invertases, $J$. Agr. Univ. P.R. 49 (3): 287-307, 1965.

3. - Action patterns of sugarcane acid invertase, J. Agr. Univ. P.R. 51 (2): 140-153, 1967.

4. - The action pattern of sugarcane-leaf amylase, J. Agr. Univ. P.R. 51 (2): 154-66, 1967.

5. - Enzyme-sugar relationships in immature sugarcane treated with ascorbic acid, cysteine, hydroxylamine, cyanide, silicon, and iron, J. Agr. Univ. P.R. 51 (1): 46-54, 1967.

6. Ayres, A. S., Calcium silicate slag as a growth stimulant for sugarcane on lowsilicon soils. Soil Sci. 101 (3): 216-27, 1966.

7. Clements, H. F., Effects of silicate on the growth and leaf freckle of sugarcane. Proc. Int. Soc. Sugar Cane Tech. 12th Cong., San Juan, P.R., 1965 (in press).

8. Dube, S. K., and Nordin, P., Isolation and properties of sorghum $\alpha$-amylase, Arch. Biochem. and Biophys. 94: 121-7, 1961.

9. Hassid, W. Z., and Ballou, C. E., in: The carbohydrates. Chapter 9, Edited by Ward Pigman. Academic Press Inc., New York, N.Y. 1957.

10. Helmcke, J. G., Die feinstruktur der kieselsaure und ihre physiologische dedeutung in diatomeenschalen. Naturwissenschaften 11: 254-5, 1954.

11. Herissey, H., Wickstrom, A., and Countois, J. E., Action of periodic acid on nonreducing trisaccharides and tetrasaccharides. II. Gentianose, Bull. Soc. Chem. Biol. 38: 1768-76, 1951. III. Stachyose, 34: 856-66, 1952.

12. Isbell, H. S., and Pigman, W. W., Pyranose-furanose interconversions with reference to the mutarotations of galactose, levulose, lactulose and turanose, $J$. Res. Natl. Bur. Stand. 20: 773-98, 1938.

13. Jorgensen, E. G., Effects of different silicon concentrations on the growth of diatoms, Physiol. Plantarum 5: 161-70, 1952.

14. - Diatom periodicity and silicon assimilation, Dansk. Botan. Arkiv. 18: 6-54, 1957. 
15. Laidlaw, R. A., and Wylam, C. B., The structure of stachyose, J. Chem. Soc. 567-71, 1953.

16. Lewin, J. C., Silicon metabolism in diatoms, II, Sources of silicon for growth of Navicula pelliculosa, Plant Physiol. s0: 129-34, 1955.

17. Lewin, R. A., Physiology and Biochemistry of algae, Academic Press, New York, N.Y., p. 449, 1962.

18. Molecular organization and function, Edited by John M. Allen, Harper and Row, New York, N.Y. 1966.

19. Quastel, J. H., and Yates, E. D., The action of dyestuffs on invertase. The nature of the union between yeast invertase and sucrose, Enzymologia 1:60-80, 1936.

20. Sumner, J. B., and O'Kane, D. J., The chemical nature of yeast saccharase, Enzymologia 12: 251-3, 1948.

21. Villiers De, and D'Hotman, O., Soil rejuvenation with crushed basalt in Mauritius. I. The Intnl. Sugar J. 63: 363-4, 1961. 